\title{
Character Education Based on Digital Comic Media
}

\author{
https://doi.org/10.3991/ijim.v14i03.12111 \\ Nofha Rina $(\bowtie)$ \\ Universitas Padjadjaran, Universitas Telkom, Bandung, Indonesia \\ nofharina80@gmail.com \\ Jenny Ratna Suminar, Ninis Agustini Damayani, Hanny Hafiar \\ Universitas Padjadjaran, Bandung, Indonesia
}

\begin{abstract}
Reading is one of the cultures in society that tends to be abandoned along with the rapid development of information technology as children nowadays tend to choose something practical as a medium for finding information. Therefore, to improve the latest learning methods through digital media, character-based literacy comics become the main choice in building positive educational values among elementary school students. This study aims to produce character-based comic media, determine the feasibility and effectiveness of character-based comic media on the development of character education for fourth grade elementary school students. This research used a development research consisting of some stages, namely: research and data collection, planning, product draft development, expert validation, expert-based revision, limited trials, improvement of the product of limited trial results, field trials, improvement of the final product, and product dissemination. The comparison test method in the field test uses Gain Analysis and Wilcoxon t-test. The subjects of this study were the fourth-grade students of the Quran Elementary School (SDQu) i.e. 26 students consisting of 6 students for limited trials and 20 students for field trials. The results of this study show that: (1) character-based comic media was produced in thematic-integrative learning, (2) the developed comic media were viewed in terms of the quality aspects of media aspects and material aspects from the experts, the teacher, and the results of students' responses were categorized very well, and (3) comic media developed effectively increased the value of student character in the learning process.
\end{abstract}

Keywords - Digital Media, Character Education, Thematic-Integrative

\section{$1 \quad$ Introduction}

Education is a conscious effort carried out by the family, community, and government through teaching activities, and/or exercises and can be carried out inside and outside the school in order to prepare students to be able to play their role correctly in the sphere of life [1]. Education makes humans try to develop the potentials that exist in themselves to be able to deal with any change that occurs in life. 
In Indonesia, the realm of education has quite complex problems starting from primary, secondary, to higher education. The Law of National Education System 2003 Article 17, Paragraph 1 and 2 state that "Primary education is a level that underlies the level of secondary education. Primary education includes Elementary School (SD) and Madrasah Ibtidaiyah (MI). Since the primary education is the underlying level to continue to the next level, the role of primary education is crucial in the treasury of human education. Primary education has a strategic position in order to instill moral values in order to build a generation of superior quality, resilient, and has a strong character.

\subsection{Character education}

Character education is basically needed since early childhood; if an individual character has been formed from an early age, it will not easily be influenced by other factors when they get older [2]. Character education is an important thing to be practiced at all levels of education. If character education has been carried out since an early age, it will be able to overcome fundamental problems in the world of education, which lately often becomes a common concern. Character education in Indonesia really needs to be developed because it will be reduce the equal of fighting among learners and other forms of juvenile delinquency in big cities such as extortion, violence (bullying), the tendency of senior domination of juniors, etc.

Even what is most needed is the desire to develop honesty in children because many students fail because of the lack of honesty, discipline, and responsibility. Samani [3] explains that in the world of education, the case of cheating either to friends or cheating through textbooks seems to be commonly found in a daily activity. Furthermore, these cases can be also found among students in undergraduate to doctoral program in which they do cheating and plagiarism in the final project.

From the aforementioned background, researchers believe that education is the frontline in shaping the nation's character. Formation of national character through education can be done by integrating character values in subjects taught at schools. This is in line with Kesuma,et al [4] explaining that character education is an education integrated with learning that occurs in all subjects, directed at strengthening and developing children's behavior as a whole, as well as strengthening or developing behaviors that are based on the grades the school refers to. Integrating character values is crucial for the readiness of students to face every problem and stage in their lives. Through education, it is expected to produce quality human beings and develop in their entirety so that they can play an active role in nation building.

\subsection{Curiculumn-based education system}

The Government of Indonesia through the Ministry of National Education continues to make various changes and renewal of the education system aiming at the generation of the Indonesian nation becomes an intelligent and at the same time characterized nation. The government's effort to make various changes and renewal in the national education system in Indonesia is by changing the curriculum. 
The 2013 Curriculum Structure with thematic-integrative learning models conducted for Elementary School levels in accordance with those listed in the 2013 Curriculum Document and the competencies to be achieved are competencies that are balanced between attitudes, skills, and knowledge [5]. Based on this description, the thematic-integrative learning model aims to develop the potential of each student to become a complete human being, not only intellectually intelligent but also emotionally and spiritually intelligent.

Kompas on July 12th, 2013 edition revealed that teachers were still unsure of the implementation of the 2013 Curriculum which would be implemented starting from July 15th, 2013 because the teacher training period was too short and it was not easy to change the teacher paradigm from conventional methods such as lecturing in front of the class to becoming a facilitator and motivator for students. Therefore, teachers as educators must be able to respond to the transition period of curriculum changes by innovating through the development of creativity in learning. One of the things teachers can is develop effective learning media, interesting, and in accordance with the characteristics of students

\subsection{Comic based-learning media}

Regarding the media functions, Orey, et al [6] argue that "media serve as delivery systems for educational communications." Thus, media has a function as a delivery system for educational communication. Then the learning media is used as an alternative source of education by teachers if providing direct learning experiences is difficult to do. Sudjana and Rivai [7] state that learning media are used to increase student knowledge practices and are probable to improve the education effects completed. In addition, Newby, et al [8] state that "the purpose of instructional media is to facilitate communication and enhance learning". Effective learning media that have a match between the characteristics of the media with the material delivered in the stages of child development is a comic. Comic can be developed as an alternative learning media. Regarding the role of comic media, Maharsi [9] states that comic has a large role in providing educational information. Arsyad [10] suggests the advantages of comics as learning media because they contain strong visual and story elements. Thus, comic media are very effective in transferring character values through characterizations in the comic story.

Comic media will facilitate the teaching and learning process, especially in realizing abstract learning concepts through more concrete examples in daily life that are loaded with character values. Sudjana \& Rivai [7] state that the main role of comic media is to be able to create students' interest in learning. This statement is reinforced by Kesuma,et al [4] stating that students in primary schools have a high interest in visual images. In addition, the advantages of presenting comics is to contain a story line that can convey messages to the public, especially in Indonesia, through fairy tales or legends to convey values and customs that apply in society. An interesting story and a strong plot can provide a mythological structure that changes the way of life of children [11]. Therefore, learning material that is packaged through a clear story line will make the subject matter last longer in students' memories and under- 
standings. During this time, the paradigm and general perception inherent in teachers in compiling learning media is that it is difficult and tiring.

In the reality, there are still many teachers who have not increased their creativity in planning, compiling, and developing instructional media that are innovative and interesting for students. As a result, many teachers remain using conventional learning media, such as blackboards and whiteboards, or instant learning media such as wall drawings, posters and maps. This has an impact on decreasing teacher creativity and student interest in learning. Jose, et al [12] state it is also significant to reminder that digital group includes students and this is a group who like things are online. We must understand that they are not only included in scholars who have a traditional education system. They grow in new high-tech environments, with their individual skill competence and they will be in an era of much competition. The results of an interview held on January $24^{\text {th }}, 2019$ with the fourth-grade teachers of Alquran Elementary School, Bandung, information show that the school implemented thematic-integrative learning but there is lack of instructional media to activate students related to authentic assessment. The available learning media include maps of Indonesia, blackboards, whiteboards and display boards of student work.

\subsection{Digital comics based on character education}

From the results of observations in the field, the researcher found that the teacher still had problems in implementing thematic-integrative learning in the classroom because the teacher merely used textbooks for students. Related to the use of media, the teacher recognized that in learning, learning media have never been used that are classified as innovative. Although the school has an LCD projector, the teacher has not been able to use it optimally. As a result, the teacher recognized that the existence of education media is very important to make the learning process effective. Many factors revealed by teachers related to constraints in media development including time, cost, and creativity. Besides, the character of the fourth grade Alquran Elementary School students is quite active as Tarkiz student. If the teacher explains in front of the class, sometimes there are those who sleep or chat with their friends, show lack of interest in reading, and have a visual type of learning style that will be easier to understand when discovering new media. Hamalik [10] states that using a media in the education development can generate new enthusiasm and ambition, show encouragement and stimulation in learning activities, and can affect psychological condition in students. Therefore, the researcher would develop a digital comic media for text material on human relations and the environment. The reason for choosing this media is because digital comics are media that make it easy for students to completely comprehend images, build imagination, then pour their ideas in a good order, and can tell coherently the story's contents so that they can be used in thematic-integrative learning. The advantage of digital comics over printed ones is that the latter have borderless capabilities (not limited by patterns and layout), then comics can make unlimited shapes, such as, widened or lengtwise. If printed comics have drawbacks to the strength of paper, then digital comics can be stored digitally, and shared to various storage media. 
Characteristics of human and environmental text material focus on reading indicators about the relationship between people and the situation so that visualization is needed. In digital comic media, there are a series of colorful images, dialog balloon texts, using flipbook software applications and panels (picture boxes) as opening books in general. However, it is digital-based and accompanied by music effects, so hopefully it can be developed as a solution to overcome a learning problem, improve learning outcomes, and can be used as a learning medium. This school has computer laboratory facilities, making it possible to apply the use of digital comics at schools. Departing from the results of observations and interviews that have been done, this is a serious problem and solutions should be immediately sought. One of which is that teachers need to grow their will and creativity, more innovative and interesting learning media in accordance with the characteristics of students, because it can improve the quality of learning. Using digital comic media is expected to create active, creative, and innovative learning and can facilitate students in understanding a material presented.

From the aforementioned explanation, this research is feasible to develop instructional media in the form of thematic-integrative comic media based on the character education so that it is necessary to take action to overcome a learning problem. The authors develop a digital comic media as a learning media on thematic-integrative learning in Tarkiz classroom with the theme of "My Healthy Life" for fourth grade students of Alquran Elementary School, Bandung City. Based on the background of the above problems, it can be taken the formulation of the problem that is the need for the development of digital comic media in thematic-integrative lessons that are feasible and effective. In accordance with the formulation of the problem, the development aims to produce digital comic media on thematic-integrative lessons with the theme of "My Healthy Life."

\subsection{A literature review of character education - developing digital media}

Digital media applications that are used by students actually were able to help their development in order to develop education in the digital world [23]. Applications contained in digital media with poor quality will be able to influence children's development, especially related to educational content so that it impacts on aspects of cognitive and social development in children [24]. Thus, educators must be able to know that a form of digital application that will be used by elementary school students must be based on high quality standards including application content in it [25]. Besides, other studies support the importance of digital-based education in which some parents who are in Greece feel challenged to be able to use digital devices that are often used by their children so that the use of digital technology can support learning for their children [26]. Furthermore, the findings of the research that educators who have the spirit of innovation to be able to use digital media through learning can significantly increase student learning experiences in the field of knowledge, especially the use of technology and media that can be aligned with curriculum objectives [27]. In recent years, the development of cellular technology can be a good and effective educational transformation tool so that school students become more creative and for educators to 
increase creativity in developing new learning content [28]. Thus, adequate content and applications can change learning methods in a positive direction, can be used more interactively through the display of more innovative features to increase students' motivation to do school work to the maximum [29].

\section{$2 \quad$ Methodology}

\subsection{Development model}

The methodology used research and development method by Borg and Gall [13]. Research and development is a method of research development to produce new products or improve existing products and test the effectiveness of these products. Researchers conducted research and development of instructional media in the system of comics on thematic-integrative subjects with material themed "My Healthy Life". The level of feasibility of thematic-integrative insructional assets in the method of digital comics with human and environmental interaction material is known through validation by expert material, validation by media experts, validation by teachers and trial use by students. Borg and Gall [22] explained the ten steps of implementing the research and development strategy as follows:

- Research and data collection includes measurement of needs, the study of literature, research on a small scale, and considerations in terms of value.

- Planning that compiles a research plan, including the capabilities needed to conduct research, the formulation of objectives to be achieved in research, research design, and in a limited scope

- Development of product concepts includes: learning materials, learning processes, and evaluation instruments.Initial field trials on six to twelve students. During the trial, researchers conducted observations, interviews and questionnaires.

- Initial field trials on six to twelve students. During the trial, researchers conducted observations, interviews and questionnaires.

- Main product revision

- Field trials, which tested more widely to 20 students of Quran elementary school as a test subject.

- Operational product revision

- A field implementation test carried out to 26 students as respondent. Analysis is complete by a questionnaire, interview, observation and analysis of the results.

- Final product revision

- Dissemination and implementation

\subsection{Trial design}

The development product trial in the form of education comic media consists of several stages, including product validation by media experts, material experts, and elementary school teachers; revision I; limited trial; revision II; field trials; revision 
III; and final product. The application stage of model development is adjusted to the needs of researchers so that the stages of R\&D model development by researchers are simplified into four development steps are:

- Data collection stage: the data collection phase is carried out to determine the learning needs in the field. The data collection stage is carried out using field studies and literature studies. Field studies were conducted to determine the need for learning resources in schools. Field studies are carried out by analyzing curricula that apply in schools, analyzing the stages of student development, and analyzing the availability of learning resources in the field. Literature study on theories related to learning sources in the form of comics for integrative thematic learning and literature studies on the subject of human and environmental interaction.

- The planning stage: the planning phase begins with the preparation of the editorial team. Then the editorial team determines the design of the comic. After the comic design is determined, a mapping of learning material will be carried out. At this planning stage, evaluation of learning resources is also planned, namely by making an evaluation grid.

- Product development stage: The product development stage begins with the material collection, material management, and finally production or publishing. The material collected in the form of features as the main dish and other materials to complete the planned rubric. After the material is collected, the material is managed by the editorial team, by selecting the material that has been collected and editing. Then the comics are ready to be produced or published.

- Validation and testing stage: Magazine have been produced, and then evaluated. The form of evaluating magazine products as a thematic learning source is validation. Validation is done in two stages. Phase I is the validation by subject matter experts and media experts. Data obtained through this stage of the feasibility of the product and the advice of experts. Suggestions are then used for product revision revision phase I. Results 1st stage used for the validation of the 2 nd by the teacher, the advice of a teacher used to revision 2. The results of the second revision is used for testing the use by students. The results of this trial in the form of student responses to the thematic-integrative learning resources.

The procedure for developing thematic-integrative education assets in the system of digital comics with the material "My Healthy Life" can be described in the following figure 1: 


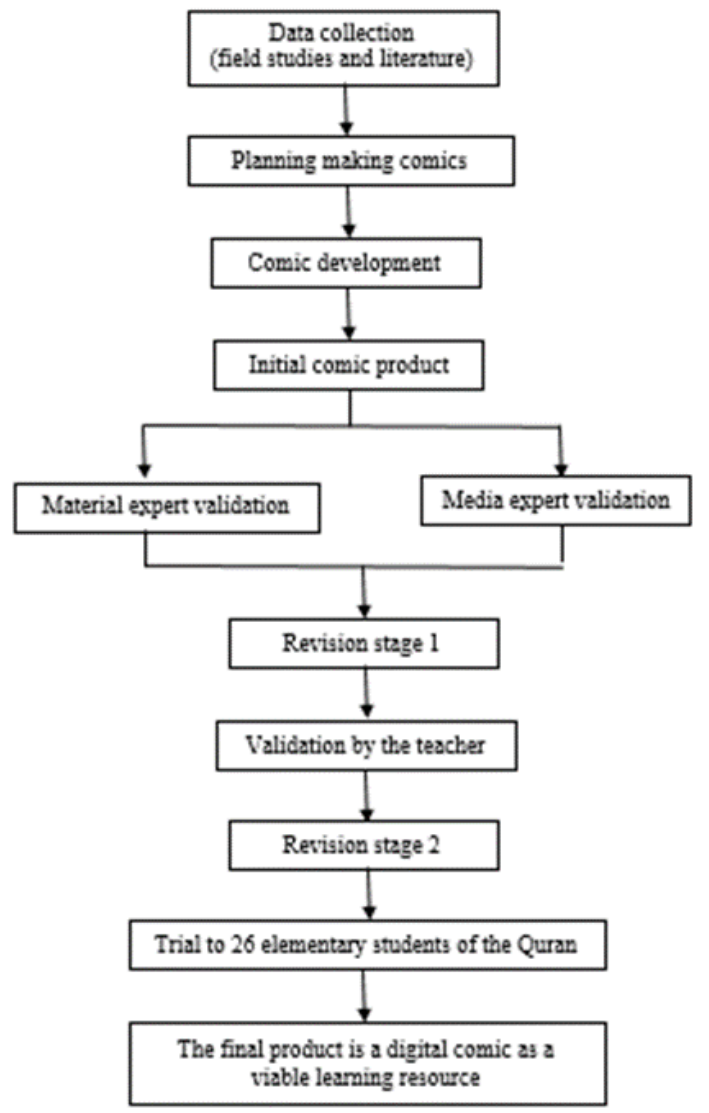

Fig. 1. Development Procedure Chart

\subsection{Trial subject}

The subject of the trial was grade IV students of Alquran Elementary School, Bandung. The limited trial subject involved 6 students, while the field trial subjects involved 20 students who had not yet been involved in the limited trial.

\subsection{Data type}

The research data in this study includes data validation of media experts and material about the feasibility of products developed in the form of comic media, student questionnaire data on comic media, data on the implementation of education by teachers and students, character questionnaire data and observations on student discipline and responsibility 


\subsection{Instrument of data collection}

The research instruments in this study are divided into two parts. First, the instruments are to measure the validity of the media including material expert validation sheets, media expert validation sheets and teacher assessment sheets. Second, the instruments are to measure the effectiveness of the media including student responses to the use of comic media, disciplinary character questionnaires and student responsibilities, disciplinary character observation questionnaires and student responsibilities, and observations of teacher and student learning accomplishments.

\subsection{Technique of data analysis}

In this study, the data are analyzed to obtain a learning tool in the form of a valid and effective media. If these requirements are met, the learning comics media products developed are suitable for use. To find out the quality of the development of comic media both from the aspect of media and material aspects, as well as to learn the students' responses to the comic, the data which are originally in the form of scores are converted into qualitative data (interval data) on a scale of four. The reference for changing the score to a scale of four according to the Technical Guidelines for Arranging the Affective Assessment Tool [32] can be shown in Table 1.

Table 1. Conversion of Actual Score into Interval Data

\begin{tabular}{|c|l|l|}
\hline Score Range & \multicolumn{1}{|c|}{ Score } & \multicolumn{1}{c|}{ Category } \\
\hline $\mathrm{Mi}+1.5 \mathrm{SD} i \leq \mathrm{X} \leq \mathrm{Mi}+3 \mathrm{SD} i$ & $\mathrm{~A}$ & Very Good \\
\hline $\mathrm{Mi}+0 \mathrm{SD} i \leq \mathrm{X}<\mathrm{Mi}+1.5 \mathrm{SD} i$ & $\mathrm{~B}$ & Good \\
\hline $\mathrm{Mi}-1.5 \mathrm{SD} i \leq \mathrm{X}<\mathrm{Mi}+0 \mathrm{SD} i$ & $\mathrm{C}$ & Quite Good \\
\hline $\mathrm{Mi}-3 \mathrm{SD} i \leq \mathrm{X}<\mathrm{Mi}-1.5 \mathrm{SD} i$ & $\mathrm{D}$ & Less Good \\
\hline
\end{tabular}

Notes:

$\mathrm{X}=$ actual score (score the student achieved)

$\mathrm{Mi}=1 / 2$ (maximum score + minimum score)

$\mathrm{SD}_{i}=1 / 6$ (maximum score - minimum score)

Maximum score $=$ number of criteria $\mathrm{X}$ maximum score

Minimum score $=$ number of criteria $\mathrm{X}$ minimum score

$$
g=\frac{\bar{x}_{\text {post }}-\bar{x}_{\text {pre }}}{100 \%-\bar{x}_{\text {pre }}}
$$

Hake [14] defines the changes that are high $(g>0.7)$, moderate $(0.7>g>0.3)$, and low $(\mathrm{g}<0.3)$. Furthermore, a comparison test is performed using paired t-test if the data are normally distributed [34], or using the Wilcoxon test if the data are not normally distributed [33]. The data normality test uses the Shapiro Wilk test because of the field test data $<50$. Changes are declared significant if the $\mathrm{p}$-value $<0.05$ and very significant if the $\mathrm{p}$-value $<0.01$. 


\section{Results and Discussion}

\subsection{Description of development}

At the beginning of the development stage, several definitions are conducted including some activities: library and field analysis. Once they are completed, it is continued with the development stage which includes the activities of making comic media drafts, collecting all materials needed in making comic media, making products, conducting reviews to get validation to media experts, material experts, and teachers proceed with the analysis and revision of the product considering the comments and suggestions from the media expert, the material, and the teacher. When the first revision process was done, the initial product of comic media is packed as a thematic-integrative learning media. Draft products that have been developed are then subjected to limited testing and field trials (at school). After revision in accordance with the input obtained in limited testing, the next comic media products tested in field trials. The field trials conducted in primary school students of the Qur'an which consists of 26 students. In this trial conducted study with comics media product development results with before-after design. Field trials were conducted to determine the feasibility of comic media that had previously been tested on a smaller scale. Moreover, it also aims to determine the effectiveness of using comics media. The data obtained from the field test are student response data, observational data on the implementation of student and teacher learning by observers, student character data before and after learning with comic media (initial questionnaire-questionnaire), and student character observation lists.

\subsection{Description of product trial}

Trials at the product validation stage by media experts, material experts, and teachers are conducted to obtain valid data from material aspects and media aspects. Minimum component validity requirements get an average score in either category. If the category has reached good, then the component has been declared feasible. Data on product validation by media experts and material experts are presented in Table 2 and Table 3, while for the product assessment results by the teacher are shown in Table 4 .

Table 2. Results of the Product Validity by Media Experts

\begin{tabular}{|c|l|c|l|}
\hline No & \multicolumn{1}{|c|}{ Evaluation Aspects } & Total Score & \multicolumn{1}{c|}{ Criteria } \\
\hline 1 & Anatomy of comics & 25.00 & Very Good \\
\hline 2 & Design and color & 15.00 & Very Good \\
\hline 3 & Overall appearance & 28.00 & Very Good \\
\hline
\end{tabular}


Table 3. Results of the Product Validity by Material Experts

\begin{tabular}{|c|l|c|l|}
\hline No & \multicolumn{1}{|c|}{ Evaluation Aspects } & Total Score & \multicolumn{1}{c|}{ Criteria } \\
\hline 1 & Material Approriateness & 23.00 & Very Good \\
\hline 2 & Material Accuracy & 16.00 & Very Good \\
\hline 3 & Material Updates & 4.00 & Very Good \\
\hline 4 & Linguistic & 20.00 & Very Good \\
\hline 5 & Character Value & 7.00 & Very Good \\
\hline
\end{tabular}

Table 4. Results of the Product Validity by Teachers

\begin{tabular}{|c|l|c|l|}
\hline No & \multicolumn{1}{|c|}{ Evaluation Aspects } & Total Score & \multicolumn{1}{c|}{ Criteria } \\
\hline 1 & Anatomy of Comics & 26.00 & Very Good \\
\hline 2 & Design and Color & 16.00 & Very Good \\
\hline 3 & Overall Appearance & 27.00 & Very Good \\
\hline 4 & Material Appropriateness & 21.00 & Very Good \\
\hline 5 & Material Accuracy & 15.00 & Very Good \\
\hline 6 & Material Updates & 4.00 & Very Good \\
\hline 7 & Linguistic & 19.00 & Very Good \\
\hline 8 & Character Value & 8.00 & Very Good \\
\hline
\end{tabular}

Based on Tables 2, 3 and 4, the results of product validation conducted by Media Experts, Material Experts and Teachers showed very good results in all aspects so that the comic media developed were considered valid and worthy of further testing. Suggestions from experts include: improving the spelling in comic media conversations, selecting the student's character to be adjusted, and correcting the position of the image so that it is more adapted to the message from the developed media. With these results, the testing process continues to the next stage, namely limited trials. The next step is the limited trial. Limited trials are given to six students at grade IV. Data generated regarding students' answers to the use of comic media during the learning process. Data on the outcomes of student responses to the use of comics can be shown in Table 5.

Table 5. Results of Student Responses to the Use of Comic Media

\begin{tabular}{|c|l|c|l|}
\hline No & \multicolumn{1}{|c|}{ Evaluation Aspects } & Total Score & \multicolumn{1}{c|}{ Criteria } \\
\hline 1 & Media & 19.17 & Very Good \\
\hline 2 & Material & 12.00 & Very Good \\
\hline 3 & Linguistic & 7.17 & Very Good \\
\hline 4 & Character & 7.33 & Very Good \\
\hline
\end{tabular}

Based on Table 5 above, the results of the analysis of student responses were obtained in the excellent category for all aspects. Media aspects of the student questionnaire included the anatomy of comics, design of comics and overall appearance. Material aspects in the student questionnaire include Material Appropriateness, Material Accuracy, and Material Updates. The advice obtained from the limited test is the use of language in comic conversations and revamping of some blurred images. Once the revision referring to the input obtained in the limited trial is complete, the comic me- 
dia product was then tried out in the field experimental or trial. Field experimental or trial were done to 20 students in grade IV. In this trial, learning was carried out with a comic media product that was developed using a before-after design. Field trials were conducted to determine the feasibility of comic media that had previously been tested on a smaller scale to define the effectiveness of the usage of comic media. The data obtained from the field test are student response data, observations of student and teacher learning outcomes by observers, student character data before and after learning with comic media (initial questionnaire- final questionnaire), and student character observation data. From the student response data, the average student assessment of learning with comic media is in the very good category. Data on the outcomes of student answers to the use of comics in field trials can be shown in Table 6.

Table 6. Student Responses to the Use of Comic Media in Field Trials $(n=20)$

\begin{tabular}{|c|l|c|l|}
\hline No & \multicolumn{1}{|c|}{ Evaluation Aspects } & Total Score & \multicolumn{1}{c|}{ Criteria } \\
\hline 1 & Media & 19.65 & Very Good \\
\hline 2 & Material & 15.50 & Very Good \\
\hline 3 & Language & 7.70 & Very Good \\
\hline 4 & Character & 7.35 & Very Good \\
\hline
\end{tabular}

From the student response data in the field test as presented in Table 6, it can be seen that the average student assessment of learning with comic media is in a very good category for the four aspects used as an assessment. These results are consistent and tend to be higher than the results of limited trials. This shows that by revising the use of language in comic conversations and the improvement of the blurry images that have been done previously proved able to increase students' responses to the use of Comic Media in learning. Data on the effectiveness of the use of comic media was obtained from observations of the implementation of student and teacher learning by observers and the character questionnaire values before and after the use of comic media. The implementation of learning by the teacher during the use of comic media from the first day to the fifth day shows the percentage of $78 \%, 82 \%, 85 \%, 95 \%$, and $100 \%$. This shows that the teacher has carried out learning activities by the learning plans that have been made. Besides learning by using comic media has reached the expected target. The results of observer calculations in the field trials show the percentage achievement in six days about $72 \%, 85 \%, 90 \%, 95 \%$, and $100 \%$. This shows that students have implemented learning activities by the learning plans that have been made and the use of comic media is in line with the expected targets. Field trials are also to find out the effectiveness of comic media in improving the character of discipline and student responsibility. Student character development, data obtained through questionnaires filled out by students and observational data by observers.

The results of the initial and final student questionnaire on the character of discipline can be seen in table 7, while in the character of responsibility can be seen in table 8 . Both tables show the value achieved by students through a questionnaire that was distributed before the trial use of comics (initial) and after the test try using comics (end). The analysis used is a descriptive approach by looking at the average value between before (initial) and after (final) the use of comic media in learning. In addi- 
tion to the descriptive approach, a Gain Analysis is also carried out to see how much change has occurred. To get the results of a more convincing analysis, a significance test of the pre and post comparisons was carried out using the Wilcoxon test.

The results of the initial and final student questionnaire on the character of discipline can be seen in Table 7, while for the character of responsibility can be shown in Table 8.

Table 7. Results of Discipline Characteristics Questionnaire in Field Trials

\begin{tabular}{|l|c|c|}
\hline \multicolumn{1}{|c|}{ Score } & Initial & Final \\
\hline Maximum & 80 & 95 \\
\hline Minimum & 60 & 85 \\
\hline Mean & 69.75 & 90.75 \\
\hline Gain & 0.69 & (Moderate) \\
\hline p-value & \multicolumn{2}{|c|}{0.000} \\
\hline
\end{tabular}

Table 8. Results of Responsibility Characteristics Questionnaire in Field Trials

\begin{tabular}{|l|c|c|}
\hline \multicolumn{1}{|c|}{ Score } & Initial & Final \\
\hline Maximum & 75 & 95 \\
\hline Minimum & 60 & 85 \\
\hline Mean & 70.00 & 90.50 \\
\hline Gain & 0.68 & (Moderate) \\
\hline p-value & \multicolumn{2}{|c|}{0.000} \\
\hline
\end{tabular}

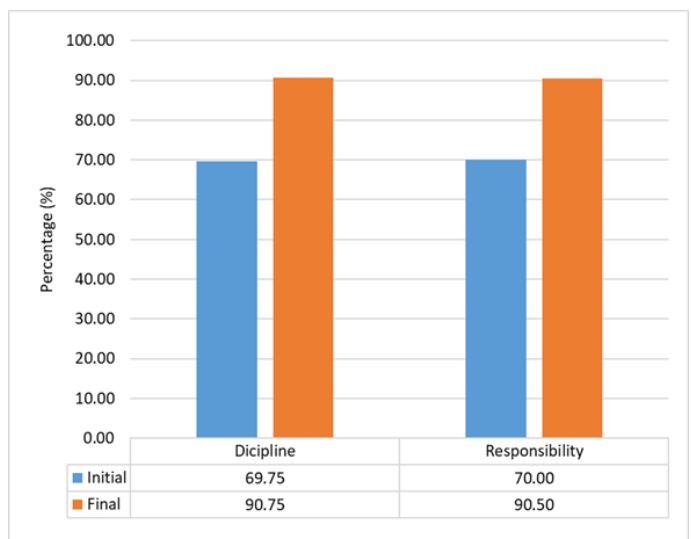

Fig. 2. Early and Late Development Achievement of Value Character Field Trial

The achievement of an increase in student discipline code shown in Table 7 and Figure 2, analyzed by using the gain. The results of the analysis of the character of student discipline questionnaires were obtained gain scores, $\langle\mathrm{g}>=0.69$. According to Hake [14], an increase in the character of discipline is included in the category of "Medium", and created arranged the results of the comparative test using the Wilcoxon test shows that an increase in the character of the discipline is declared very significant ( $p$-value $<0.01$ ). These results indicate that the use of Comic Media in learning 
can improve the character of student discipline. Achievement of increasing the character of student responsibility is shown in Table 8 and Figure 2, also analyzed using the gain technique. The results of the questionnaire analysis of the character of student responsibility obtained gain score, $\langle\mathrm{g}>=0.68$. The increase in the character of responsibility According to Hake [14], included in the category of "Moderate", and arranged the results the results of a comparative test using the Wilcoxon test showed that the increase in the character of responsibility was stated to be very significant ( $\mathrm{p}$ value $<0.01$ ). These results indicate that the use of Comic Media in learning can improve the character of student responsibility. In addition to using a questionnaire, the development of discipline, character values, and student responsibility is also seen through observation techniques observed by observers of 20 students in field trials. The results of observations on the achievement of Discipline and Responsibility of students from the first meeting to the fifth meeting can be shown in Table 9 and visually presented in Figure 3.

Table 9. Data of Character Observation in Field Trials

\begin{tabular}{|c|l|c|c|c|c|c|}
\hline \multirow{2}{*}{ No } & \multirow{2}{*}{$\begin{array}{c}\text { Character } \\
\text { Value }\end{array}$} & \multicolumn{5}{|c|}{ Meeting } \\
\cline { 3 - 7 } & & $\boldsymbol{I}$ & $\boldsymbol{I I}$ & $\boldsymbol{I I I}$ & $\boldsymbol{I}$ & $\boldsymbol{V}$ \\
\hline 1 & Discipline & 69.25 & 73.50 & 78.25 & 83.25 & 89.25 \\
\hline 2 & Responsibility & 70.25 & 74.50 & 79.00 & 84.00 & 90.75 \\
\hline
\end{tabular}

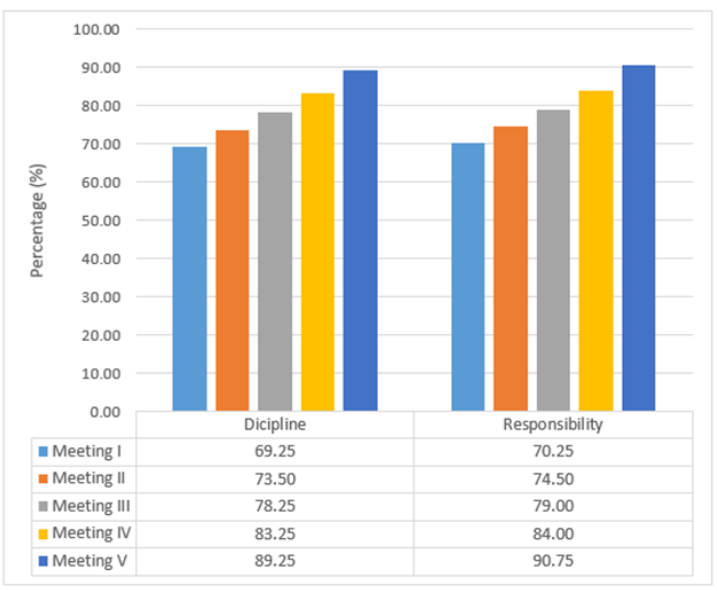

Fig. 3. Results of Observation of Disciplinary Character and Student Responsibility in Field Trials

The observations above give results that are in line with the results of responses in the previous field test, where an increase in the discipline character of students from $69.25 \%$ on the first day to $89.25 \%$ on the fifth day of observation or an increase of $20 \%$. Likewise, the results of observations showed an increase in the character of student responsibility from the first day by $70.25 \%$ to $90.75 \%$ on the fifth day of observation or an increase of $20.5 \%$. Based on the results of the analysis, the develop- 
ment of discipline character and responsibility through this comic media as a whole is said to be "effective". Character values conveyed through characters in comics have a positive impact on students who read the comics. Children in the concrete operational stage will be able to understand things that appear or like the reality they observe. Who they model and what they see can be the basis for shaping their character in the future. The improvement of character through comic media is closely related to the characteristics of other comics, namely the strength of the storyline. Comics that can be categorized as picture books can convey messages through the storyline. The message conveyed by comic artists can flow to the reader without being influenced by anything [16]. Thematic-integrative learning that uses character-based comic media based on the results has proven to be effective in improving the character of discipline and responsibility. G. Kokkalia et al [17] and Agathi et al [19] have stated that there are several studies that explain that digital education activities that are well designed can be used as an important educational tool to achieve an efficient and effective learning especially in the field of literacy skills.

Comics function as a medium that can be utilized by teachers in instructional activities. The correct use of comic media can make the classroom atmosphere more effective and conducive during learning. This is because teacher activities in the classroom have a real role to increase the intensify of education and the capability of educators to use the developed comic media has an effect on learning success. There are two methods to reflect about using technology in learning: additional media for existing educational practice or as agents of transformation that facilitate the maximum increase in lifelong learning and goals wherever you want and whenever you want [18]. The obtained results of validation from media experts, material experts, and teachers, all aspects of comics including aspects of comic anatomy, design and color, overall appearance, material appropriateness, material accuracy, material update, language, as well as characters, show a "Very good" rating. The developed comic media is considered feasible if all aspects assessed reach the minimum "Good" category. Therefore, character-based comic media for thematic-integrative learning is feasible and ready for further testing.

The main objective of developing this comic media is to stimulate student attention in instructional and improve the personality of students' discipline and responsibility. The results of field trials, it is known that the use of comic media in education has an influence on improving the discipline characteristics of grade IV students of Alquran Elementary School. The percentage between the score before and after the character questionnaire show that students' discipline achieved the gain score of $<\mathrm{g}>=0.62$ and included in the "medium" category, meaning that there has been growth in the discipline personality of the grade IV students of Alqurna Elementary School. The developed comic media can help improve the discipline character of grade IV students of Alquran Elementary School in a "moderate" rate of increase. More interactive technology tools can be used by elementary school students that can increase student motivation, student involvement in learning and ultimately can generate student learning interest [20]. On the other hand, active learning techniques can result in storing material in students' brains up to $90 \%$ so that it can be assumed that learning runs effectively [21]. Digital learning comic is packaged in the system of a DVD (Digital Video 
Disc) and the contents include: 1) Learning objectives, 2) Characters in comics, 3) Colored digital images, 4) Music accompaniment Effect, 5) Cartoon image format, 6) Image sequence of a story, 7) Narration that is packaged in balloon text, and 8) Type of font such as Arial, Comic and Sans. Accompanying material includes a guidebook for utilizing and operating digital comic media, which contains product identity, preparation steps before using media, instructions for media use, lesson plans, syllabus, and how to maintain the media.

Furthermore, the use of comic media in learning has an influence on increasing the character of the responsibility of grade IV students of Alquran Elementary School. Percentage between the pretest and posttest scores of the students' responsibility based on the analysis using the gain score obtained $<\mathrm{g}>=0.66$ and categorized in "medium" category, meaning that there has been an increase in the character of responsibility of grade IV students of Alquran Elementary School. The developed comic media can help improve the character of the responsibility of grade IV students of Alquran Elementary School in a "moderate" rate of increase. In addition to using questionnaires, the effectiveness of using comic media to improve the character of students' discipline and responsibility is also seen through the results of observations as shown in Table 9. There is an increase in characters that appear in students. These results are in line with the increase obtained from the results of the questionnaire. Thus, it can be said that the "effective" comic media is used as a tool for character education.

Based on the results of the final study, information can be obtained that the quality of the developed comic media has been used in the thematic-integrative learning of the grade IV of Alquran Elementary School. Thus, character-based comic media can be implemented based on the objectives to be achieved namely to improve the character of discipline and responsibility of grade IV students of Alquran Elementary School.

\subsection{Implication of this study for alquran elementary school students}

The development of digital learning technology which is very rapid and reaching all over the world has been utilized by various countries, institutions, and experts for various interests including in education and learning. Efforts are being made to develop software (application programs) that can support the improvement of the quality of education or learning in packaging digital learning materials so that the material can be accessed and socialized through digital learning. So related to digital learning requires educators to be able to have an understanding and innovative thinking about the use of digital media in the field of learning. This is because digital comic-based digital media used in learning is a more effective communication tool in the learning process in the classroom to achieve educational goals based on the 2013 education curriculum in Indonesia. The aim of this study to developing digital comics in character education in this research is to stimulate student interest in learning and improve character education based on discipline and responsibility. The character of discipline and responsibility built-in students through digital comic media ultimately forms a scientific attitude of students because this scientific attitude is a representation of 
learning activities that greatly affect student academic achievement at school. The real application of students in this research is related to the character of discipline and responsibility, which is having a very strong curiosity about the community, the environment and the phenomena around them by prioritizing evidence in supporting their conclusions about things that happen around them. Also, they can accept differences in point of view to find a match in different opinions or arguments but can be held accountable for the decisions they have. Thus, character education is an effort made deliberately to develop good character objectively both for individuals and society. So, it can be concluded that a good attitude is obtained from character education that is intentionally instilled in a person so that students can behave well. The thematicintegrative digital comic that was developed was based on character education solely aimed at giving character reinforcement to students so that civilized culture is embedded which is expected to be a positive habit for students in learning activities.

The linkage of the inculcation of character values with learning material has a function to build a national identity. Starting from the identity which is potential in realizing character building, through environmental influences, efforts to actualize the potential from within and the internalization of values from outside and the personal will of the person concerned. This is what will produce the character that underlies our attitudes and behavior that can produce the appearance of behavior such as manners and moral appearance. So, a person who has character is not good enough but a person who has character is a person who is both good and able to use the good value through a struggle to achieve the noble goal that is declared. Its strengths can help educators in drawing important conclusions about students' behavior, processes, and learning needs [31].

\subsection{Limitation of the study and future research}

Although this character education has been designed within the scope of digital learning there are some limitations in its use, including the sample size in this study is too minor so it will be problematic to catch a significant relationship from the data. Ideally, statistical tests generally need a bigger sample size to confirm a population distribution that is representative and is measured descriptive of the group of respondents for which the results will be generalized and will be highly irrelevant if the sample size is used in qualitative research to explain the context of the research problem. Thus, the lack of data held in this research then there are limitations in the scope of the analysis so that it becomes an obstacle in finding meaningful relationships in the results obtained. So that this can be a necessity for future research to be able to expand again in taking samples and using different methods to collect data comprehensively. Considering this, it is necessary to make a comprehensive model for evaluating various types of educational applications. So for further research, parents can be included for elementary school students in developing digital comics to build student character education both at school and at home. For further research can be developed on the use of literature and the use of the digital world in digital games that can build the character education of a nation's students so that it can lead to a positive relationship of active learning and student outcomes [30]. 


\section{Conclusion}

From the results and discussion of this study, the improvement of comic media can be determined as follows:

- Character-based comic media can be developed for thematic-integrative learning which is appropriate for grade IV students of Alquran Elementary School. The results of validation from media experts, material experts, and teachers show that all aspects of comics including comic anatomy, design and color, overall appearance, material appropriateness, material accuracy, material update, language, as well as character show a "Very good" rating. This proves that the comic media development based on characters is valid and feasible to be used in learning activities for grade IV of Alquran Elementary School.

- The character-based comic media developed have been proven to be effective in increasing the character of discipline and responsibility of grade IV students of Alquran Elementary School. The efficiency of comic media can be seen from the data obtained through questionnaire sheets and student character observation sheets. In addition to using a questionnaire, an increase in the character of students' discipline and responsibility is also observed through observation techniques showing the percentage of discipline and responsibility characters which increased from observation in the first meeting to the sixth meeting. Comics as learning media in the Quran elementary school are examples of the application of educational technology. In this case included in the area of design and development, namely the design of resources for learning and development of resources for learning. Therefore, comic media in learning are very important to be developed in this research so that the messages in comics as a learning medium can manipulate the physical form of messages to be delivered by teachers in schools. The physical form, in this case, in the form of text and visual through print technology that is of higher quality. This can make student character education through digital comic media can be realized perfectly in the elementary school environment because forming character, discipline, and responsibility for school students with ages between 7 to 11 years is not easy. Finally, the more assessment in terms of comic aspects as well as an increase in terms of the character of discipline and responsibility of students, it means there is an increase in student motivation through learning messages delivered with comic media, the content and style of delivery of messages on digital comics can provide new stimuli in learning, and there is feedback that occurs effectively through material in learning comics.

\section{$5 \quad$ References}

[1] Rohman, A. (2009).Memahami Pendidikan Dan Ilmu Pendidikan. Yogyakarta: Laks-Bang Mediatama.

[2] Azzet, A., M. (2011). Urgensi Pendidikan Karakter Di Indonesia. Yogyakarta:Ar-Ruzz Media. 
[3] Samani, M. (2013). Pendidikan Konsep Dan Model Karakter. Bandung: PT Remaja Rosdakarya.

[4] Kesuma, D., Trianta, C., \& Permana, J. (2012). Pendidikan Karakter: Kajian Teori Dan Praktik Di Sekolah. Bandung: PT Remaja Rosdakarya.

[5] Kemendikbud. (2012). Dokumen Kurikulum 2013. Jakarta: Kemdikbud.

[6] Orey, M., McClendon, V. J., \& Branch, R. M. (2006). Educational Media And Technology Yearbook. Santa Barbara: Libraries Unlimited.

[7] Sudjana, N., \& Rivai, A. (2010). Media Pengajaran. Bandung: Penerbit Sinar Baru Algensindo.

[8] Timothy, J., N., Donald, S., James, L., James, D., R., \& Anne, T., L. (2011). Educational Technology For Teaching And Learning, 4th Edition. Upper Saddle River: Pearson Education, Inc.

[9] Maharsi, I. (2010) Komik Dunia Kreatif Tanpa Batas. Yogyakarta: Kata Buku.

[10] Arsyad, Azhar. (2013). Media Pembelajaran (Edisi Revisi). Jakarata: Raja Grafindo Persada.

[11] Humphrey, M. (2005). Living The Hero's Quest: Character Building Through Action Research. London: Libraries Unlimited.

[12] José B., Mauro, F., \& Carlos, N. (2015). Interactive Design and Gamification of eBooks for Mobile and Contextual Learning. International Journal of Interactive Mobile Technologies 9, (3), pp. 24. https://doi.org/10.3991/ijim.v9i3.4421.

[13] Borg, W. \& Gall, M. (1998). Educational Research: An introduction 4th Edtion. New York. Longman Inc.

[14] Hake, R., R. (1998). Intercative-Engagement Versus Traditional Method: A Six-ThousandStudent Survey Of Mechanics Test Data For Introductory Physics Courses. American Association of Physics Teachers 66, pp.64-74. https://doi.org/10.1119/1.18809

[15] Saptono. (2011). Dimensi-Dimensi Pendidikan Karakter. Salatiga: Esensi.

[16] McCloud, S. (2001). Memahami Komik (Translated By S. Kinanti From The Original Title: Understanding Comics: The Invisible Art). Jakarta: Kepustakaan Populer Gramedia (KPG).

[17] Kokkalia., A., S., Drigas, \& Alexandra, E. (2016). Mobile Learning For Preschool Education. International Journal of Interactive Mobile Technologies 10, (4), pp. 5764.https://doi.org/10.3991/ijim.v10i4.6021

[18] Athanasios, S., D., \& Pantelis, A. (2017). Mobile Applications Within Education: An Overview of Application Paradigms in Specific Categories. International Journal of Interactive Mobile Technologies 11, (4), pp. 17-29. https://doi.org/10.3991/ijim. v11i4.6589

[19] Agathi S., Zoe K., Alexandra E., \& Athanasios D. (2018). Mobile Assessment Procedures for Mental Health and Literacy Skills in Education. International Journal of Interactive Mobile Technologies 12, (3), pp. 21-37. https://doi.org/10.3991/ijim.v12i3.8038.

[20] Elizabeth, J., Soh, H., M., Abdul, H., A., Mahani, M., \& Nornazira., S. (2018).Using Digital Smartboard to Overcome Order Thinking Skills Learning Difficulties in Data Handling among Primary School Students. International Journal of Interactive Mobile Technologies 12, (7), pp. 43-57. https://doi.org/10.3991/ijim.v12i7.9644.

[21] Soh, H., M., Abdul, H., A., Mahani, M., Dayana., F., A., \& Khairul Anuar, A., R. (2019). Active Learning Using Digital Smartboard to Enhance Primary School Students's Learning. International Journal of Interactive Mobile Technologies 13, (7), pp. 416.https://doi.org/10.3991/ijim.v13i07.10654.

[22] Sukmadinata, N., S. (2006). Metode Penelitian Pendidikan. Bandung: PT.Remaja Rosdakarya. 
[23] Papadakis, S., Kalogiannakis, M., \& Zaranis, N. (2017). Designing And Creating An Educational App Rubric For Preschool Teachers. Education and Information Technologies 22(6), pp. 3147-3165. https://doi.org/10.1007/s10639-017-9579-0

[24] Papadakis S., Kalogiannakis M. \& Zaranis N. (2018). Educational Apps From The Android Google Play For Greek Preschoolers: A Systematic Review. Computers \& Education 116, pp. 139-160. https://doi.org/10.1016/j.compedu.2017.09.007

[25] Kalogiannakis, M., \& Papadakis, St. (2018). An Evaluation of Greek Eductional Android Apps for Pre-Schoolers. In Finlayson, O., McLoughlin, E., Erduran, S., \& Childs, P. (Eds.), Electronic Proceedings of the ESERA 2017 Conference. Research, Practice and Collaboration in Science Education, Part 4/Strand 4 (co-ed. Kalle Juuti \& Eleni A. Kyza, Digital Resources for Science Teaching and Learning), pp.593-603. Dublin, Ireland: Dublin City University. ISBN 978-1-873769-84-3.

[26] Papadakis, S., Kalogiannakis, M., \& Zaranis, N. (2019). Parental Involvement And Attitudes Towards Young Greek Children's Mobile Usage. International Journal of ChildComputer Interaction. https://doi.org/10.1016/j.ijcci.2019.100144.

[27] Papadakis, S. (2020). Apps to Promote Computational Thinking Concepts and Coding Skills in Children of Preschool and Pre-Primary School Age. In S. Papadakis, \& M. Kalogiannakis (Eds.). Mobile Learning Applications in Early Childhood Education, pp.101121. Hershey, PA: IGI Globahttps://doi.org/10.4018/978-1-7998-1486-3.ch006.

[28] Kalogiannakis, M., \& Papadakis, S. (2020). The Use of Developmentally Mobile Applications for Preparing Pre-Service Teachers to Promote STEM Activities in Preschool Classrooms. In S. Papadakis, \& M. Kalogiannakis (Eds.), Mobile Learning Applications in Early Childhood Education, pp. 82-100. Hershey, PA: IGI Global. https://oi.org/10. 4018/978-1-7998-1486-3.ch005

[29] Papadakis, St., \& Kalogiannakis, M. (2020). A Research Synthesis of the Educational Value of Self-proclaimed Mobile Educational Applications for Young Age Children. In S. Papadakis, \& M. Kalogiannakis (Eds.). Mobile Learning Applications in Early Childhood Education, pp.1-19. Hershey, PA: IGI Global. https://doi.org/10.4018/978-1-7998-14863.ch001.

[30] Papadakis, S. (2018). The Use Of Computer Games In Classroom Environment. International Journal of Teaching and Case Studies, 9(1), 1-25. Retrieved from https://www.inderscience.com/info/ingeneral/forthcoming.php?jcode=ijtcs. https://doi.org/10.1504/IJTCS.2018.10011113

[31] Vidakis, N., Barianos, A.-K., Trampas, A.-M., Papadakis, St. Kalogiannakis, M., \& Vassilakis, K. (2019). Generating Education in-Game Data: The Case of an Ancient Theatre Serious Game. In B. McLaren, R. Reilly, S. Zvacek, \& J. Uhomoibhi (Eds). Proceedings of the 11th International Conference on Computer Supported Education (CSEDU 2019),1, 36-43, Heraklion, Crete, Greece, 2-4 May. https://doi.org/10.5220/00078108 $\underline{00360043}$

[32] Direktorat Pembinaan SMA. (2010). Juknis Penyusunan Perangkat Penilaian Afektif di SMA. Jakarta : Direktorat Pembinaan Sekolah Menengah Atas Direktorat Jenderal Pendidikan Dasar dan Menengah Kementerian Pendidikan dan Kebudayaan.

[33] Siegel Sidney and N. John Castellan (1988). Nonparametric Statistics for The Behavioral Sciences, 2nd Edition. Michigan : McGraw-Hill.

[34] Mark, L., B., David, M., L., \& Timothy, C., K. (2012). Basic Business Statistics: Concepts and Aplications. New Jersey: Prentice Hall. 


\section{Authors}

Nofha Rina is Ph.D student at Universitas Padjadjaran and a lecturer at Universitas Telkom, Bandung, Indonesia. She is a researcher who has the concentration on topics related to digital literacy, instructional communication, and family communication and also a member of the Association of the Indonesian Communication Science Journal Manager (APJIKI). Email: nofharina80@gmail.com

Jenny Ratna Suminar is the Chairman of the Master of Communication Sciences, Graduate School, Universitas Padjadjaran, Bandung, Indonesia. Her research fields are interpersonal communication, communication psychology, therapeutic communication. She has great interests to examine the world of human communication issues regarding their relationship in it.

Ninis Agustini Damayani is a senior lecturer at the Faculty of Communication Science, Universitas Padjadjaran, Indonesia. Her research fields are marketing for non-profit organization, preservation of culture and manuscript, literacy and community development, disaster literacy and communication, health literacy and cultural literacy.

Hanny Hafiar is a senior lecturer at the Faculty of Communication Science and the Editor-in-Chief of the Jurnal Kajian Komunikasi (JKK) at Universitas Padjadjaran, Bandung, Indonesia. She is a researcher who has the concentration on topics related to disability and active in conducting socialization regarding disability to early childhood.

Article submitted 2019-10-29. Resubmitted 2019-12-07. Final acceptance 2019-12-07. Final version published as submitted by the authors. 